\title{
ANALISIS KUALITAS PELAYANAN TERHADAP LOYALITAS NASABAH PADA BANK JATENG CABANG PEMBANTU SAMPANGAN
}

\author{
Ardhila Laela Kusumastuti *) \\ M. Abdul Kodir **)
}

ABSTRACT

This study aims to determine and measure the effect of Service Quality variables on Customer Loyalty at Bank Jateng Branch of Sampangan.

The data in this research is obtained by filling the questionnaire to 100 customers of Bank Jateng Sampangan Branch Office. Sampling using purposive sampling method while data testing method is done by Test Validity, Test Reliability, Classic Assumption Test, $t$ test, F test, and Coefficient of Determination. Data analysis method used is multiple linear regression analysis with SPSS program version 24.

The result of testing the hypothesis indicate that there are significant effects both simultally and partislly on service quality variable to customer loyalty at Bank Jateng Sampangan Branch Office and variable of Reliability is dominant variable that influence to customer loyalty at Bank Jateng Branch of Sampangan.

Keywords: service quality, customer loyalty

*) Mahasiswa Tugas Akhir Prodi Keuangan dan Perbankan, Jurusan Akuntansi, Politeknik Negeri Semarang

**) Dosen Jurusan Akuntansi, Politeknik Negeri Semarang

\section{PENDAHULUAN}

\section{Latar Belakang}

Pertumbuhan ekonomi suatu bangsa dapat ditandai dengan tumbuhnya industri perbankan di negara tersebut. Semakin berkembang industri perbankan tersebut semakin berkembang pula suatu bangsa. Menurut data OJK 2017, jumlah Bank Umum di Indonesia sebanyak 115.

Gambar 1

Data Jumlah Bak Umum di Indonesia

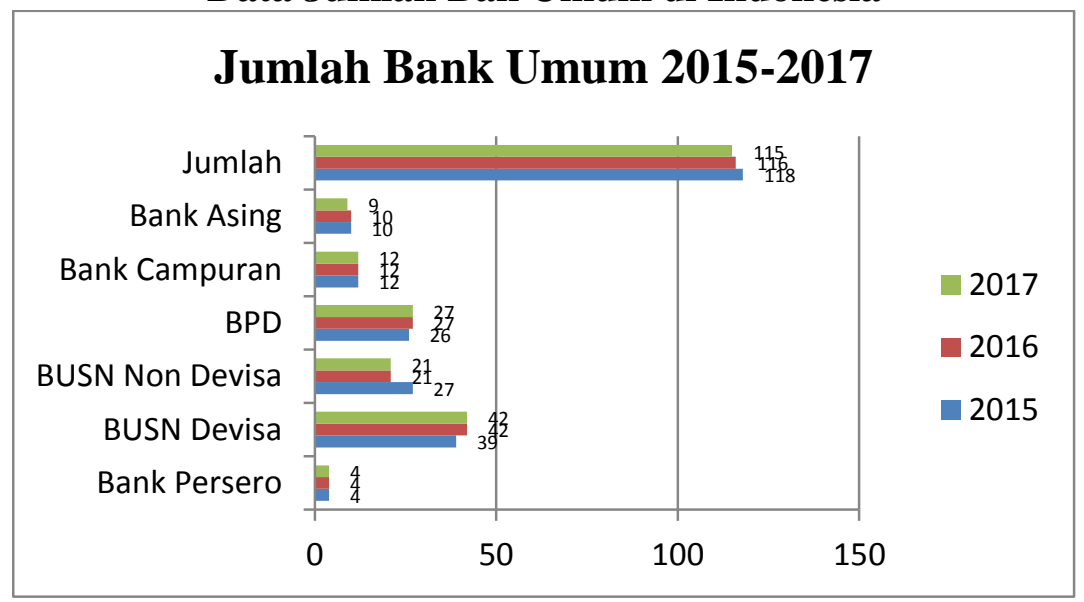

Sumber : Statistik Perbankan Indonesia, Vol 16 Nomor 1, Desember 2017 
Jumlah tersebut telah berkurang dari tahun 2013 yang sebelumnya berjumlah 120 bank. Dengan banyaknya jumlah bank di Indonesia, maka persaingan di industri perbankan sangat tinggi untuk tetap unggul dan eksis. Untuk bisa mencapai tujuan unggul dan eksis tersebut, setiap bank melakukan banyak cara dan strategi dalam inovasi produk maupun layanan. Hal ini supaya pelanggan atau nasabah mereka merasa puas dan tetap bertahan atas tawaran pesaing lain. Kepuasan pelanggan merupakan salah satu faktor yang menentukan apakah seorang pelanggan akan loyal atau tidak pada suatu usaha jasa tertentu (Costabile, 2001 dalam Jasfar 2012) dan loyalitas pelanggan merupakan hal yang diinginkan oleh setiap perusahaan, terutama perusahaan jasa seperti perbankan. Lovelock dan Wright (2005:380) mengemukakan bahwa loyalitas pelanggan merupakan kesediaan pelanggan untuk terus berlangganan pada suatu perusahaan dalam jangka panjang, dengan membeli dan menggunakan barang atau jasanya secara berulangulang, serta sukarela merekomendasikan barang atau jasa perusahaan tersebut kepada teman dan kerabat.

Loyalitas pelanggan dikenal sebagai faktor yang signifikan dalam organisasi yang sukses. Oleh karena itu jelas bahwa keberhasilan loyalitas pelanggan dalam organisasi bisnis secara signifikan lebih penting daripada kepuasan pelanggan (Taleghani et.al 2011 dalam Rangan, 2015). Hal ini selaras dengan pendapat dari Jones dan Sasser (1995) yang menyimpulkan bahwa dengan hanya memuaskan pelanggan adalah tidak cukup menjaga mereka untuk tetap loyal, sementara mereka bebas untuk membuat pilihan. Strewart (1997) juga menyimpulkan adalah keliru untuk mengemukakan asumsi bahwa kepuasan dan loyalitas adalah bergerak bersama-sama (dalam Oliver, 1999).

Produk - produk dan jasa yang ditawarkan oleh setiap bank memang bisa jadi sama, yang membedakan adalah bagaimana suatu bank memberikan service performance kepada nasabahnya. Performa tersebut dapat dirasakan oleh nasabah melalui pelayanan yang diberikan. Oleh karena itu, peningkatan kualitas pelayanan menjadi indikator yang harus ada dan terus diperbaiki, sehingga dapat menjadi keunggulan bersaing untuk industri perbankan.

Kualitas pelayanan merupakan salah satu faktor yang penting bagi keberhasilan suatu perusahaan jasa perbankan. Hal tersebut juga diungkapkan pada penelitian yang menyatakan bahwa salah satu 
faktor penting yang dapat membuat pelanggan puas adalah kualitas jasa (Shellyana dan Basu, 2002:93). Jika pelayanan yang diberikan baik kepada nasabah maka akan berpengaruh positif terhadap kinerja usaha, begitu sebaliknya bila kualitas pelayanan buruk maka akan berpengaruh negatif terhadap kinerja usaha. Raksadipoera (1997) tentang kualitas pelayanan dikatakan bahwa lebih dari $65 \%$ pelanggan suatu LKB/LKBB berpindah ke LKB/LKBB pesaing karena alasan service delivery quality, antara lain karena kurang mendapat perhatian sebanyak $20 \%$ dan $45 \%$ karena alasan pelayanan yang tidak ramah (dalam Hadiwidjaja, 2017).

Kualitas dan promosi menjadi faktor kunci untuk menciptakan loyalitas pelanggan jangka panjang. Penelitian yang dilakukan oleh Sabihaini (2002) dalam Mardalis (2005) menyimpulkan bahwa peningkatan kualitas jasa akan memberikan dampak yang baik untuk meningkatkan loyalitas. Hal yang sama juga diungkapkan oleh Bloomer, Ruyter dan Peeters (1998) mendapatkan kualitas jasa memiliki pengaruh langsung terhadap loyalitas dan mempengaruhi loyalitas melalui kepuasan.

Menurut Bloomer, (1998:277) pada tingkat dimensi yang mendasari konstruksi tersebut menjadi jelas bahwa kehandalan (dimensi kualitas) dan segmentasi pasar (dimensi image) merupakan penggerak yang relatif penting dari loyalitas bank ritel. Hal ini seperti yang diungkapkan oleh Dick dan Basu (1994), yang menyatakan bahwa atribut tidak berwujud seperti kehandalan dan keyakinan dapat memainkan peran utama dalam membangun/mempertahankan loyalitas (dalam Oliver, 1999).

Masyarakat sebagai konsumen atau pasar yang dituju oleh industri perbankan memiliki berbagai pertimbangan dalam memilih jasa perbankan yang akan digunakan. Hal ini dikarenakan semakin cerdasnya masyarakat, kesadaran harga, dan banyak produk yang mulai bermunculan, serta keterbukaan teknologi informasi yang berperan untuk menuntut kepekaan dalam merespon setiap perubahan. Sehingga bank dituntut untuk menghasilkan produk-produk sesuai kebutuhan nasabah, yang dapat membentuk loyalitas nasabah terhadap produk tersebut.

Di kota Semarang khususnya, telah berdiri beberapa bank yang menawarkan jasa perbankan, baik bank yang dimiliki oleh pihak pemerintah maupun pihak swasta. Di antaranya, Bank Rakyat Indonesia (BRI), Bank Negara Indonesia (BNI), Bank Mandiri, Bank Tabungan Negara (BTN), 
Bank Pembangunan Daerah (BPD) Jawa Tengah dan lain sebagainya. Kehadiran bank-bank tersebut, secara ekonomi memberikan keuntungan kepada masyarakat umum khususnya para pelaku ekonomi.

Bank Pembangunan Daerah (BPD) Jawa Tengah yang kini berubah nama menjadi Bank Jateng merupakan satu-satunya Bank Daerah yang berguna untuk meningkatkan perekonomian masyarakat khususnya di Jawa Tengah. Bank Jateng didirikan pada tahun 1963 yang dipelopori oleh Pemerintah Daerah beserta tokoh masyarakat dan tokoh pengusaha swasta di Jawa Tengah, atas dasar diperlukan lembaga perekonomian yang berbentuk bank untuk membantu pemerintah dalam hal pembangunan daerah. Dengan hadirnya Bank Jateng yang merupakan satu-satunya bank milik daerah di Jawa Tengah, maka Bank Jateng juga tidak boleh lengah terhadap tingginya tingkat persaingan di industri perbankan.

Kualitas pelayanan yang diberikan oleh Bank Jateng dalam hal ini Bank Jateng Cabang Pembantu Sampangan, akan mendorong nasabah untuk menjalin ikatan yang kuat dengan perusahaan. Dalam jangka panjang, ikatan ini akan berdampak pada pemahaman kebutuhan nasabah dan harapan nasabah untuk perusahaan. Apabila nasabah merasa puas atas kualitas pelayanan yang diberikan, maka nasabah akan semakin loyal. Berdasarkan data statistik keuangan Bank Jateng Cabang Pembantu Sampangan, perkembangan jumlah nasabah pada tahun 2015-2017 sebagai berikut :

Tabel 1

Jumlah Nasabah Tabungan Bank Jateng Cabang Pembantu Sampangan tahun 2015-2017

\begin{tabular}{|l|l|l|l|}
\hline \multirow{2}{*}{\multicolumn{1}{|c|}{ Produk }} & \multicolumn{3}{c|}{ Jumlah Nasabah (orang) } \\
\cline { 2 - 4 } & \multicolumn{2}{|c|}{2015} & \multicolumn{2}{c|}{2016} & 2017 \\
\hline Tabungan & & & 3.397 \\
\hline a. Bima & 2.744 & 3.140 & 408 \\
\hline b. Simpeda & 466 & 529 & 604 \\
\hline c. Hiprada & 3.600 & 3.160 & 496 \\
\hline d. Tabunganku & 385 & 469 & 543 \\
\hline e. Simpel & - & 127 & 5.448 \\
\hline Jumlah & 7.195 & 7.425 & \\
\hline
\end{tabular}

Sumber : Bank Jateng Cabang Pembantu Sampangan

Berdasarkan Tabel 1.1 dapat dijelaskan bahwa jumlah nasabah Bank Jateng Cabang Pembantu Sampangan mengalami peningkatan pada tahun 2016 dengan jumlah 7.425 nasabah dari sebelumnya berjumlah 7.195 nasabah. Namun, jumlah tersebut mengalami penurunan yang 
signifikan pada tahun 2017 menjadi 5.488 nasabah. Hal ini menjadi perhatian untuk dicermati. Apabila terjadi peningkatan jumlah nasabah tabungan, maka ini menandakan adanya loyalitas

nasabah yang meningkat pada Bank Jateng Cabang Pembantu Sampangan, begitu sebaliknya apabila terjadi penurunan terhadap jumlah nasabah, maka tingkat loyalitas nasabah pada Bank Jateng Cabang Sampangan juga menurun.

Berdasarkan latar belakang dan tabel 1.1 di atas, maka dalam penelitian ini peneliti tertarik untuk memilih Bank Pembangunan Daerah Jawa Tengah atau yang disebut dengan Bank Jateng sebagai objek penelitian khususnya Bank Jateng Cabang Pembantu Sampangan dengan pokok permasalahan, apakah kualitas pelayanan berpengaruh dalam peningkatan loyalitas nasabah pada Bank Jateng Cabang Pembantu Sampangan. Penelitian ini bertujuan untuk mengetahui seperti apa dan bagaimana pengaruhnya kualitas pelayanan yang diberikan terhadap loyalitas nasabah. Karenanya perlu dilakukan kajian lebih mendalam mengenai kualitas pelayanan dan loyalitas nasabah pada Bank Jateng Cabang Pembantu Sampangan melalui penelitian

\section{Rumusan Masalah}

Berdasarkan latar belakang di atas, dapat dikatakan bahwa permasalahan yang dialami oleh Bank Jateng Cabang Pembantu Sampangan adalah penurunan jumlah nasabah yang signifikan. Penurunan jumlah nasabah disebabkan oleh banyaknya nasabah yang menutup rekening miliknya pada tahun 2017. Disamping itu, berdasarkan keragaman hasil penelitian yang dilakukan oleh Pramana dan Rastini (2016), Hadiwijadja (2017), Wattymury (2012), Novitasari (2017), Dewi, Yasa, dan Sukaatmadja (2014), Ismail (2014), dan Zulfitri (2012). Sehingga dalam penelitian ini dapat dirumuskan kedalam pertanyaan penelitian sebagai berikut :

a. Apakah variabel kualitas pelayanan secara serempak berpengaruh signifikan terhadap loyalitas nasabah pada Bank Jateng Cabang Pembantu Sampangan?

b. Apakah variabel bukti fisik, kehandalan, daya tanggap, jaminan dan empati secara parsial berpengaruh terhadap loyalitas nasabah pada Bank Jateng Cabang Pembantu Sampangan?

c. Variabel mana yang relatif lebih dominan berpengaruh terhadap loyalitas nasabah pada Bank Jateng Cabang Pembantu Sampangan? 


\section{Tujuan Penelitian}

Berdasarkan permasalahan dalam penelitian ini, maka tujuan dari penelitian ini adalah sebagai berikut :

a. Untuk mengetahui dan mengukur variabel kualitas pelayanan berpengaruh secara serempak terhadap loyalitas nasabah pada Bank Jateng Cabang Pembantu Sampangan.

b. Untuk mengetahui dan mengukur variabel bukti fisik, kehandalan, daya tanggap, jaminan, dan empati berpengaruh secara parsial terhadap loyalitas nasabah pada Bank Jateng Cabang Pembantu Sampangan.

c. Untuk mengetahui dan mengukur variabel mana yang relatif lebih dominan berpengaruh terhadap loyalitas nasabah pada Bank Jateng Cabang Pembantu Sampangan.

\section{KAJIAN TEORI}

\section{Kualitas Pelayanan}

Dalam rangka menciptakan kepuasan pelanggan yang akan membetuk loyalitas nasabah, produk yang ditawarkan harus berkualitas. Istilah kualitas sendiri mengandung berbagai macam penafsiran, sehingga perusahaan harus dapat menjaga kualitas jasa yang ditawarkan berada diatas pesaing dan lebih hebat dari yang dibayangkan oleh pelanggan. Apabila kualitas yang diterima lebih baik atau sama dengan yang dibayangkan, maka pelanggan akan mencobanya kembali. Akan tetapi bila perceived services atau pelayanan yang dirasakan lebih rendah dari expected service atau pelayanan yang diharapkan, maka pelanggan akan kecewa sehingga berakibat berhentinya hubungan antara pelanggan dengan perusahaan jasa terkait.

Kualitas pelayanan adalah suatu ukuran yang digunakan sebagai penilaian atas pelayanan yang diberikan kepada pelanggannya atau nasabah. Kualitas pelayanan juga merupakan strategi dalam manajemen pemasaran dan menjadi faktor dominan dalam keberhasilan suatu organisaasi.

Pada tahun 1988, Parasuraman, Zeithaml dan Berry menyederhanakan kesepuluh dimensi kualitas pelayanan menjadi lima dimensi pokok berikut (dalam Tjiptono, 2009:269):

1. Reliabilitas

Kemampuan memberikan layanan yang dijanjikan dengan segera, akurat, dan memuaskan.

2. Daya Tanggap 
Keinginan para staf untuk membantu para pelanggan dan memberikan layanan dengan tanggap..

\section{Jaminan}

Mencakup pengetahuan, kompetensi, kesopanan, dan sifat dapat dipercaya yang dimiliki para staf, bebas dari bahaya, risiko atau keragu-raguan.

\section{Empati}

Meliputi kemudahan dalam menjalin relasi, komunikasi yang baik, perhatian pribadi, dan pemahaman atas kebutuhan individual para pelanggan.

\section{Bukti Fisik}

Meliputi fasilitas fisik, perlengkapan, pegawai, dan sarana komunikasi.

\section{Loyalitas Pelanggan}

Loyalitas pelanggan menurut Lovelock dan Wright (2002:380) mengemukakakn bahwa loyalitas pelanggan merupakan kesediaan pelanggan untuk terus berlangganan pada suatu perusahaan dalam jangka panjang, dengan membeli dan menggunakan barang atau jasanya secara berulangulang, serta dengan sukarela merekomendasikan barang atau jasa perusahaan tersebut kepada teman dan kerabat.

Sedangkan menurut Lupiyoadi (2013:231) kajian-kajian loyalitas pelanggan dikategorikan menjadi tiga kategori: pendekatan perilaku, pendekatan sikap, dan pendekatan integrasi. Pendekatan perilaku berfokus pada perilaku konsumen purna pembelian dan mengukur loyalitas berdasarkan tingkat pembelian, frekuensi, dan kemungkinan membeli lagi. Pendekatan sikap menyimpulkan loyalitas pelanggan dari aspek keterlibatan psikologis, favoritisme, dan sense of goodwill pada jasa tertentu. Pendekatan integrasi mengombinasikan dua variabel untuk menciptakan konsep loyalitas pelanggan secara terpisah. Dengan mencoba mengadopsi pendekatan ini dalam menyusun model, sehingga konsep loyalitas pelanggan dipahami sebagai kombinasi sikap senang pelanggan dan perilaku pembelian ulang. 


\section{Jenis-jenis Loyalitas Konsumen}

Menurut Jill Griffin (2005:22) terdapat empat jenis loyalitas yang muncul bila keterikatan rendah dan tinggi diklasifikasi-silang dengan pola pembelian ulang, yang rendah dan tinggi. Adapun jenisjenis loyalitas konsumen yaitu :

1. Tanpa Loyalitas

Untuk berbagai alasan tertentu, ada beberapa konsumen yang tidak mengembangkan loyalitas atau kesetiaan kepada suatu produk maupun jasa tertentu. Tingkat keterikatan yang rendah dengan tingkat pembelian ulang yang rendah menunjukkan absennya suatu kesetiaan. Pada dasarnya, suatu usaha harus menghindari kelompok no loyaltyini untuk dijadikan target pasar, karena mereka tidak akan menjadi konsumen yang setia.

2. Loyalitas yang Lemah (Inertia Loyalty)

Inertia loyalty merupakan sebuah jenis loyalitas konsumen yang dimana adanya keterikatan yang rendah dengan pembelian ulang yang tinggi. Konsumen yang memiliki sikap ini biasanya membeli berdasarkan kebiasaan. Dasar yang digunakan untuk pembelian produk atau jasa disebabkan oleh faktor kemudahan situasional. Kesetiaan semacam ini biasanya banyak terjadi terhadap produk atau jasa yang sering dipakai. Contoh dari kesetiaan ini terlihat dari kegiatan pembelian bensin yang dilakukan konsumen di dekat daerah rumahnya dan sebagainya.

3. Loyalitas Tersembunyi (Laten Loyalty)

Jenis loyalitas tersembunyi merupakan sebuah kesetiaan atau keterikatan yang relatif tinggi yang disertai dengan tingkat pembelian ulang yang rendah. Konsumen yang mempunyai sikap laten loyalty pembelian ulang juga didasarkan pada pengaruh faktor situasional daripada sikapnya. Sebagai contoh, seorang suami menyukai masakan Eropa, tetapi mempunyai istri yang kurang menyukai masakan Eropa. Maka suami tersebut hanya sesekali saja mengunjungi restoran Eropa dan lebih sering pergi ke restoran yang dimana masakan yang ditawarkan dapat dinikmati bersama.

\section{Loyalitas Premium (Premium Loyalty)}

Loyalitas ini merupakan yang terjadi bilamana suatu tingkat keterikatan tinggi yang berjalan selaras dengan aktivitas pembelian kembali. Setiap perusahaan tentunya sangat mengharapkan kesetiaan jenis ini dari setiap usaha preference yang tinggi. Contoh jenis premium loyalty adalah rasa bangga yang muncul ketika konsumen menemukan dan menggunakan produk atau 
jasa tersebut dan dengan senang hati membagi pengetahuan dan merekomendasikannya kepada teman, keluarga, maupun orang lain.

\section{Hipotesis}

Berdasarkan pada permasalahan dan tujuan penelitian yang diuraikan sebelumnya, maka hipotesis yang diajukan dalam penelitian ini adalah :

H1 : diduga kualitas pelayanan secara serempak berpengaruh signifikan terhadap loyalitas nasabah pada Bank Jateng Cabang Pembantu Sampangan.

H2 : diduga variabel bukti fisik, kehandalan, daya tanggap, jaminan dan empati secara parsial berpengaruh terhadap loyalitas nasabah pada Bank Jateng Cabang Pembantu Sampangan.

\section{METODE}

Penelitian ini menggunakan jenis penelitian kausalitas, yaitu penelitian yang ingin mencari penjelasan dalam bentuk hubungan sebab-akibat (cause-effect) antar beberapa konsep atau beberapa variabel. Populasi dalam penelitian ini adalah nasabah pada Bank Jateng Cabang Pembantu Sampangan. Metode penentuan sampel yang digunakan dalam penelitian ini adalah purposive sampling, yaitu pengambilan sampel dengan menetapkan kriteria tertentu. Sampel pada penelitian ini adalah sejumlah nasabah pada Bank Jateng Cabang Pembantu Sampangan. Dalam penelitian ini akan diambil 100 sampel dengan menggunakan kuesioner sebagai alat pengumpul data pokok dan observasi.

\section{HASIL DAN PEMBAHASAN}

\section{Karakteristik Responden}

Karakteristik responden bertujuan untuk mendeskripsikan mengenai nasabah Bank Jateng Capem Sampangan. Karakteristik tersebut meliputi jenis kelamin, usia, dan pekerjaan. Dari 100 responden, $48 \%$ berjenis kelamin laki-laki dan 52\% perempuan. Responden paling banyak berusia lebih dari 40 tahun dengan persentase 35\% diikuti dengan usia antara 33-40 tahun (25\%), 17-24 tahun (23\%), dan terendah pada usia 25-32 tahun dengan persentase 17\%. Berdasarkan pekerjaan dari 100 responden paling banyak adalah sebagai PNS sebesar 32\%. 
Tabel 2

Karakteristik Responden

\begin{tabular}{cccc}
\hline No & Jenis Kelamin & Frekuensi (orang) & Jumlah Persentase (\%) \\
\hline 1 & Laki-laki & 48 & $48 \%$ \\
2 & Perempuan & 52 & $52 \%$ \\
& Jumlah & 100 & $100 \%$ \\
\hline No & Usia & Frekuensi (orang) & Jumlah Persentase (\%) \\
\hline 1 & $17-24$ & 23 & $23 \%$ \\
2 & $25-32$ & 17 & $17 \%$ \\
3 & $33-40$ & 25 & $25 \%$ \\
4 & $>40$ & 35 & $35 \%$ \\
& Jumlah & 100 & $100 \%$ \\
\hline No & Pekerjaan & Frekuensi (orang) & Jumlah Persentase (\%) \\
\hline 1 & Pelajar / Mahasiswa & 23 & $23 \%$ \\
2 & Wiraswasta & 10 & $10 \%$ \\
3 & PNS & 32 & $17 \%$ \\
4 & Karyawan Swasta & 17 & $18 \%$ \\
5 & Lainnya & 18 & $100 \%$ \\
& Jumlah & 100 &
\end{tabular}

Sumber : Data Primer yang diolah, 2018

\section{Uji Validitas}

Uji Validitas dilakukan untuk mengetahui buti-butir pernyataan tersebut valid atau tidak. Tabel 3 menunjukkan bahwa seluruh indikator pada variabel bukti fisik, kehandalan, daya tanggap, jaminan dan empati serta loyalitas nasabah memiliki $r$ hitung lebih besar dari $r$ tabel dan nilai probabilitas 0,000 lebih kecil dari nilai signifikan 0,05 sehingga seluruh indikator memenuhi syarat validitas data.

Tabel 3

Hasil Pengujian Validitas

\begin{tabular}{|c|c|c|c|c|c|}
\hline No & $\begin{array}{c}\text { Butir dalam } \\
\text { Kuesioner }\end{array}$ & $\begin{array}{c}\text { Koefisien } \\
\text { Korelasi }\end{array}$ & $\begin{array}{c}\text { Nilai } \\
\text { Kritis }\end{array}$ & $\begin{array}{c}\text { Taraf sig }(\dot{\alpha} \\
=0,05)\end{array}$ & Keterangan \\
\hline 1 & Y1.1 & 0,704 & 0,1966 & 0,000 & Valid \\
\hline 2 & Y1.2 & 0,677 & 0,1966 & 0,000 & Valid \\
\hline 3 & Y1.3 & 0,656 & 0,1966 & 0,000 & Valid \\
\hline 4 & Y1.4 & 0,67 & 0,1966 & 0,000 & Valid \\
\hline 5 & $\mathrm{X} 1.1$ & 0,622 & 0,1966 & 0,000 & Valid \\
\hline 6 & $\mathrm{X} 1.2$ & 0,712 & 0,1966 & 0,000 & Valid \\
\hline 7 & $\mathrm{X} 1.3$ & 0,776 & 0,1966 & 0,000 & Valid \\
\hline
\end{tabular}




\begin{tabular}{|c|c|c|c|c|c|}
8 & X1.4 & 0,711 & 0,1966 & 0,000 & Valid \\
\hline 9 & $\mathrm{X} 2.1$ & 0,851 & 0,1966 & 0,000 & Valid \\
\hline 10 & $\mathrm{X} 2.2$ & 0,788 & 0,1966 & 0,000 & Valid \\
\hline 11 & $\mathrm{X} 2.3$ & 0,814 & 0,1966 & 0,000 & Valid \\
\hline 12 & $\mathrm{X} 2.4$ & 0,781 & 0,1966 & 0,000 & Valid \\
\hline 13 & $\mathrm{X} 3.1$ & 0,614 & 0,1966 & 0,000 & Valid \\
\hline 14 & $\mathrm{X} 3.2$ & 0,772 & 0,1966 & 0,000 & Valid \\
\hline 15 & $\mathrm{X} 3.3$ & 0,626 & 0,1966 & 0,000 & Valid \\
\hline 16 & $\mathrm{X} 3.4$ & 0,691 & 0,1966 & 0,000 & Valid \\
\hline 17 & $\mathrm{X} 4.1$ & 0,626 & 0,1966 & 0,000 & Valid \\
\hline 18 & $\mathrm{X} 4.2$ & 0,797 & 0,1966 & 0,000 & Valid \\
\hline 19 & $\mathrm{X} 4.3$ & 0,695 & 0,1966 & 0,000 & Valid \\
\hline 20 & $\mathrm{X} 4.4$ & 0,754 & 0,1966 & 0,000 & Valid \\
\hline 21 & $\mathrm{X} 5.1$ & 0,691 & 0,1966 & 0,000 & Valid \\
\hline 22 & $\mathrm{X} 5.2$ & 0,608 & 0,1966 & 0,000 & Valid \\
\hline 23 & $\mathrm{X} 5.3$ & 0,728 & 0,1966 & 0,000 & Valid \\
\hline 24 & $\mathrm{X} 5.4$ & 0,717 & 0,1966 & 0,000 & Valid \\
\hline
\end{tabular}

Sumber : data primer yang diolah, 2018

\section{Uji Reliabilitas}

Berdasarkan Tabel 4 menunjukkan bahwa variabel independen dan variabel dependen memiliki koefisien Cronbach Alpha's lebih besar dari 0,60 sehingga pernyataan pada kuesioner tersebut reliabel.

Tabel 4

Hasil Pengujian Reliabilitas

\begin{tabular}{|c|c|c|c|}
\hline No & $\begin{array}{c}\text { Butir dalam } \\
\text { Kuesioner }\end{array}$ & Nilai Alpha & Keterangan \\
\hline 1 & $\mathrm{Y}$ & 0,833 & Reliabel \\
\hline 2 & $\mathrm{X} 1$ & 0,858 & Reliabel \\
\hline 3 & $\mathrm{X} 2$ & 0,916 & Reliabel \\
\hline 4 & $\mathrm{X} 3$ & 0,838 & Reliabel \\
\hline 5 & $\mathrm{X} 4$ & 0,866 & Reliabel \\
\hline 6 & $\mathrm{X} 5$ & 0,847 & Reliabel \\
\hline
\end{tabular}

Sumber: data primer yang diolah, 2018 


\section{Pembahasan Hasil Analisis}

Pada penelitian ini digunakan analisis regresi linier berganda. Ringkasan hasil analisis menggunakan SPSS dapat dilihat pada Tabel 5 berikut:

Tabel 5

Hasil Analisis Regresi Linier Berganda

\begin{tabular}{|c|c|c|c|c|}
\hline \multirow{2}{*}{\multicolumn{2}{|c|}{ Model }} & $\begin{array}{c}\text { Unstandardized } \\
\text { Coefficients }\end{array}$ & $\mathrm{T}$ & Sig. \\
\hline & & B & & \\
\hline \multirow[t]{6}{*}{1} & (Constant) &,- 969 & $-1,050$ & ,296 \\
\hline & BUKTI_FISIK &, 132 & 2,140 & ,035 \\
\hline & KEHANDALAN & 251 & 3,915 & ,000 \\
\hline & DAYA_TANGGAP & ,218 & 3,324 & ,001 \\
\hline & JAMINAN & ,223 & 3,847 & ,000 \\
\hline & EMPATI & 259 & 3,509 & ,001 \\
\hline \multicolumn{5}{|c|}{ Adjusted $\mathrm{R}^{2}=0,756 \quad$ Sig $\mathrm{F}=0,000$} \\
\hline \multicolumn{5}{|c|}{ Fhitung $=62,398$} \\
\hline \multicolumn{5}{|c|}{ Durbin Watson $=2,073$} \\
\hline
\end{tabular}

Sumber : data primer yang diolah, 2018

Dari hasil analisis regresi linier berganda diperoleh persamaan regresi berganda sebagai berikut : $\mathrm{Y}=-0,969+0,132 \mathrm{X} 1+0,251 \mathrm{X} 2+0,218 \mathrm{X} 3+0,223 \mathrm{X} 4+0,259 \mathrm{X} 5+$ e. Persamaan tersebut menunjukkan bahwa variabel independen memiliki pengaruh positif terhadap loyalitas nasabah pada Bank Jateng Cabang Pembantu Sampangan.

Besarnya pengaruh variabel independen secara keseluruhan ditunjukkan oleh nilai koefisien Adjusted $\mathrm{R}^{2}$ sebesar 0,756 atau 75,6\% variabel independen mempunyai pengaruh terhadap loyalitas nasabah pada Bank Jateng Cabang Pembantu Sampangan. Sedangkan sisanya 24,4\% dipengaruhi oleh faktor lain yang tidak disebutkan dalam penelitian ini.

Berdasarkan hasil analisis melalui uji $\mathrm{F}$ diperoleh $\mathrm{F}$ hitung sebesar 62,398 > F tabel yang hanya sebesar 2,31 dari taraf signifikansi 0,05 yang artinya bahwa variabel bukti fisik, kehandalan, daya tanggap, jaminan dan empati secara serempak berpengaruh terhadap loyalitas nasabah. Hal ini dapat dilihat dari kondisi ruangan Bank Jateng Cabang Pembantu Sampangan dengan interior dan eksterior yang menarik, dan karyawan yang berbusana rapi. Bank Jateng Cabang Pembantu Sampangan juga telah menunjukkan dari segi pelayanan yang mampu memahami setiap kebutuhan 
nasabah dan dapat menangani keluhan nasabah secara tepat. Karyawan yang terpercaya, keamanan saat bertransaksi serta tersedianya fasilitas yang lengkap.

Hasil uji t pada Tabel 5 menunjukkan bahwa secara parsial variabel bukti fisik, kehandalan, daya tanggap, jaminan, dan empati berpengaruh signifikan terhadap loyalitas nasabah pada Bank Jateng Cabang Pembantu Sampangan. Hal ini dapat dilihat berdasarkan uji t. Hasil uji t secara berturutturut di uraikan sebagai berikut :

\section{Bukti Fisik}

Berdasarkan hasil pengujian dapat dilihat nilai t hitung variabel bukti fisik sebesar 2,140>t tabel dengan besar signifikansi 0,035 yang menunjukkan besarnya signifikansi kurang dari 0,05. Pengaruh signifikan ini karena nasabah pada Bank Jateng Cabang Pembantu Sampangan menganggap bahwa dari segi fasilitas fisik bank, kerapian busana karyawan dan kelengkapan peralatan sudah memadai.

\section{Kehandalan}

Nilai t hitung variabel kehandalan sebesar 3,915 > t tabel dengan besar signifikansi 0,000 yang menunjukkan besarnya signifikansi kurang dari 0,05. Nasabah pada Bank Jateng Cabang Pembantu Sampangan menganggap bahwa Bank Jateng Cabang Pembantu Sampangan dapat menangani kebutuhan nasabah dengan tepat, serta memperhatikan kualitas sistem pelayanan yang dijanjikan.

\section{Daya Tanggap}

Nilai t hitung daya tanggap sebesar 3,324>t tabel dengan besar signifikansi 0,000 yang menunjukkan besarnya signifikansi kurang dari 0,05. Pengaruh signifikan ini karena bank mampu merespon setiap kebutuhan dan menangani keluhan nasabah dalam menemukan solusi terbaik.

\section{Jaminan}

Nilai t hitung variabel jaminan sebesar 3,847 > t tabel dengan besar signifikansi 0,000 yang menunjukkan besarnya signifikansi kurang dari 0,05. Sistem manajemen serta karyawan Bank Jateng Cabang Pembantu Sampangan yang dinilai baik dan positif oleh nasabah. Penilaian tersebut 
dapat dilihat dari karyawan yang ramah, dan rasa aman yang diciptakan oleh pihak Bank Jateng, sehingga nasabah merasa tenang untuk melakukan transaksi.

\section{Empati}

Nilai t hitung variabel empati sebesar 3,509>t tabel dengan besar signifikansi 0,001 yang menunjukkan besarnya signifikansi kurang dari 0,05. Pengaruh signifikan ini berasal dari kepekaan bank dalam menyediakan hal-hal terkecil. Misalnya, tempat menunggu. Nasabah akan jenuh saat menuggu antrian sehingga diperlukan tempat menunggu yang membuat nasabah merasa nyaman.

\section{PENUTUP}

Berdasarkan hasil analisis dan pembahasan yang telah dilakukan dalam penelitian ini, variabel kualitas pelayanan berpengaruh serempak maupun parsial terhadap loyalitas nasabah pada Bank Jateng Cabang Pembantu Sampangan. Pada penelitian ini dinyatakan bahwa instrumen yang digunakan adalah valid dan reliabel. Data yang diperoleh juga terdistribusi secara normal, dengan uji asumsi klasik yang telah dilakukan menggunakan uji normalitas, uji autokorelasi, uji multikolinearitas, dan uji heteroskedastisitas menunjukkan bahwa variabel-variabel yang digunakan tidak ada yang menyimpang. Sehingga, mengindikasikan bahwa data yang ada telah memenuhi syarat untuk menggunakan model persamaan regresi linier berganda. Variabel Kehandalan berpengaruh dominan terhadap loyalitas nasabah pada Bank Jateng Capem Sampangan, artinya dari manajemen sitem pelayanan Bank Jateng sudah baik. Pada variabel lain seperti jaminan, empati, daya tanggap dan bukti fisik perlu dilakukan kaji ulang sehingga akan menciptakan kondisi yang dapat membuat nasabah menjadi lebih loyal.

\section{DAFTAR PUSTAKA}

Bloemer, Ruyter dan Peeters. 1998. Investigating Drivers of Bank Loyalty: the Complex Relationship between Image, Service Quality and Satisfaction. International Journal of Bank Marketing. Vol 16/7, pp.276-286.

Ferdinand, Augusty. 2014. Metode Penelitian Manajemen. Semarang. Badan Penerbit Universitas Diponegoro. 
Ghozali, Imam. 2016. Aplikasi Analisis Multivariate dengan Program SPSS 23. Cetakan VIII. Semarang: Badan Penerbit Universitas Diponegoro.

Griffin, Jill. 2005. Customer Loyalty Menumbuhkan \& Mempertahankan Kesetiaan Pelanggan. Jakarta: Erlangga.

Hadiwidjaja, Rini D. 2017. Analisis Pengaruh Kualitas Pelayanan terhadap Loyalitas Nasabah Baitul Maal wat Tamwil. Jurnal Ilmu Akuntansi. Vol 10 No 2.

Lovelock., et al. 2005. Service Marketing In Asia. Singapore: Pearson Prentice Hall.

Lupiyoadi, Rambat. 2013. Manajemen Pemasaran Jasa. Jakarta : Salemba Empat.

Mardalis, Ahmad. 2005. Meraih Loyalitas Pelanggan. Benefit. Vol 9 No 2.

Oliver, Ricard L. 1999. Whence Consumer Loyalty?. Journal of Marketing. Vol 63 (special issue), pp. 33-44.

Otoritas Jasa Keuangan. 2017. Statistik Perbankan Indonesia. Volume 16 No 1.

Pramana, I Gede dan Ni Made Rastini. 2016. Pengaruh Kualitas Pelayanan terhadap kepercayaan Nasabah dan Loyalitas Nasabah Bank Mandiri Cabang Veteran Denpasar Bali. E-Jurnal Manajemen Universitas Udayana. Volume 5, Nomor 1.

Rangan, Febry. 2015. Analisis Pengaruh Relationship Marketing dan Kualitas Pelayanan terhadap Kepuasan dan Loyalitas Nasabah pada PT. Pegadaian (Persero) Cabang Manado Utara. Jurnal Riset Bisnis dan Manajemen. Volume 3, Nomor 3.

Shellyana dan Basu. 2002. Pengaruh Ketidakpuasan Konsumen, Karakteristik Kategori Produk,

Dan Kebutuhan Mencari Variasi Terhadap Keputusan Perpindahan Merek. Jurnal Ekonomi dan Bisnis Indonesia. Vol 17, No 1.

Tjiptono, Fandy. 2007. Service, Quality \& Satisfaction. Yogyakarta: Andi Offset.

---------------. 2009. Service Marketing Esensi \& Aplikasi. Yogyakarta: Marknesis.

Wattimury, Ferry. 2012. Analisis Kualitas Pelayanan terhadap Loyalitas Nasabah pada Bank Mandiri Cabang Pattimura Ambon. Benchmark. Vol 1 No 1.

Zulfitri. 2012. Pengaruh Kualitas Pelayanan terhadap Loyalitas Nasabah Bank Mega Syariah Cabang di Jakarta. Jurnal Ilmu Ekonomi dan Sosial Jilid 1, Nomor 2. 